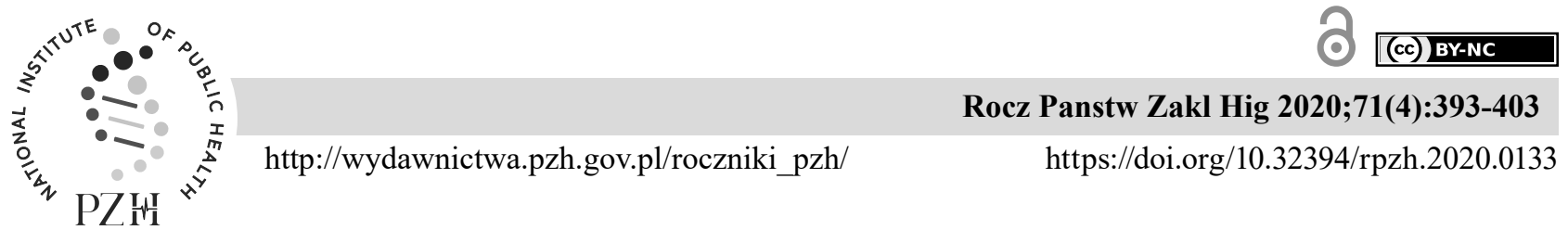

ORIGINAL ARTICLE

\title{
EFFECT OF DIETARY COMPONENTS AND NUTRITIONAL STATUS ON THE DEVELOPMENT OF PRE-SCHOOL CHILDREN
}

\author{
Beata Zyśk $k^{l}$ Ewa Stefańskal, Lucyna Ostrowska \\ ${ }^{1}$ Department of Dietetics and Clinical Nutrition, Faculty of Health Sciences, \\ Medical University of Białystok, Poland
}

\begin{abstract}
Background. The preschool period is a time of intensive changes: physical, motoric, cognitive, emotional and social development of the child. The diet should provide optimal energy andnutrient levels. Due to their properties, some of the dietary components may be particularly important in child development procesess. These include omega-3 fatty acids, B vitamins, vitamin D, antioxidants, iron, calcium, magnesium, zinc and copper.

Objective. The aim of the study was to determine the effect of selected dietary components, the nutritional status and sleep duration in children at pre-school ages (3-6-years old) on their emotional sphere, as well as the cognitive, physical and social development.

Material and methods. Anonymous research was carried out among 75 randomly selected children aged 3-6 years old in the Municipal Kindergarten in Ruciane-Nida. Research methods consited of a questionnaire, a 3-day food record, growth charts, and standardized development observation sheets. Software used for evaluation and analysis of obtained results was Diet 5.0. and Statistica 13.

Results. It was observed that the increase of the BMI percentile correlated with a lesser social development of children. Children who slept a recommended number of hours presented higher level of cognitive developmnent. High level of cognitive development was more common in children supplementing vitamin D. Higher intake of folates, vitamin D, vitamin E, magnesium, zinc and copper correlated positively with a higher level of cognitive development.

Conclusions. Application of the proper nutrition and healthy lifestyle principles supports a proper child development. All dietary components should be balanced, however some nutrients are of especial significance during the childhood development and therefore their optimal intake is essential for this developmental period.
\end{abstract}

Key words: preschool children; child development; vitamins; minerals; nutritional status;

\section{STRESZCZENIE}

Wprowadzenie. Okres przedszkolny to czas intensywnego rozwoju: fizycznego, motorycznego, poznawczego, emocjonalnego i społecznego dziecka. Dieta powinna mieć optymalną wartość energetyczną i odżywczą. Właściwości niektórych składników diety wskazują, że mogą być one szczególnie istotne w procesach rozwojowych dziecka. Należą do nich: kwasy tłuszczowe omega-3, witaminy z grupy B, witamina D, antyoksydanty, żelazo, wapń, magnez, cynk i miedź.

Cel badań. Celem badań było ustalenie wpływu wybranych składników diety, stanu odżywienia oraz długości snu dzieci w wieku przedszkolnym (3-6-letnich) na ich poziom rozwoju poznawczego, fizycznego, a także sferę emocjonalną i rozwój społeczny.

Material i metody. Anonimowe badania przeprowadzono wśród wybranych losowo 75 dzieci w wieku 3-6 lat w Przedszkolu Miejskim w Rucianem-Nidzie. Narzędziami badawczymi, zastosowanymi w pracy były: autorski kwestionariusz ankiety, 3-dniowy dzienniczek żywieniowy, siatki centylowe oraz standaryzowane arkusze obserwacji rozwoju dzieci. Do oceny i analizy uzyskanych wyników użyto programów komputerowych: Dieta 5.0. i Statistica 13. Wyniki. Stwierdzono, że wzrost centyla wskaźnika BMI korelował z gorszym rozwojem społecznym dzieci. Zalecany czas snu dla dzieci w tym wieku był skorelowany z wyższym poziomem ich rozwoju poznawczego. Wysoki poziom rozwoju kognitywnego występował częściej u dzieci suplementujących witaminę D. Zaobserwowano dodatnie korelacje pomiędzy większym spożyciem folianów, witaminy D, witaminy E, magnezu, cynku i miedzi a wyższym poziomem rozwoju poznawczego. Wnioski. Stosowanie zasad prawidłowego żywienia i zdrowego stylu życia wspomaga odpowiedni rozwój dziecka. Dieta powinna być odpowiednio zbilansowana pod względem wszystkich składników diety, ale niektóre z nich wykazują szczególny wpływ na prawidłowy przebieg procesów rozwojowych w dzieciństwie i ich optymalna podaż jest bardzo istotna w tym okresie rozwojowym.

Słowa kluczowe: dzieci w wieku przedszkolnym; rozwój dziecka; witaminy; składniki mineralne; stan odżywienia;

Corresponding author: Ewa Stefańska, Department of Dietetics and Clinical Nutrition, Medical University of Bialystok, Mieszka I-go 4B Street, 15-054 Bialystok, Poland, phone: +48 8573282 44, e-mail: estef@umb.edu.pl

(C) Copyright by the National Institute of Public Health - National Institute of Hygiene 


\section{INTRODUCTION}

The pre-school period is characterized by intensive growth and development of a humanbody. Child development is healthy if it occurs correctly and is ageadequate in all spheres: physical, motor, emotional, cognitive and social. Any disfunctions in one of the spheres may adversely affect the others [34].

Diet and lifestyle affect the development processes. These factors also shape current behavior and future habits of a person and affect their health status not only in childhood, but also in adulthood. A child's diet should be based on healthy nutrition principles and adapted to their age-adequate energy and nutrient requirements. Home ( $25 \%$ of total daily requirement) and kindergarten ( $75 \%$ of total daily requirement) nutrition should complement each other and together, form a balanced daily food ration. The development process is also supported by non-nutritional factors, such as adequate physical activity, optimal sleep duration and avoidance of stress $[6,12,37]$.

Due to their properties, some of the dietary components may be particularly important in child development procesess. Omega-3 fatty acids help ensure the proper functioning of neurons and neuronal membranes. Lipid mediators, which are omega-3 fatty acids derivatives, have anti-inflammatory and neuroprotective effects $[1,33]$. B vitamins are involved in the metabolism of homocysteine, high concentrations of which may contribute to cognitive decline $[1,33]$. Copper and antioxidant deficiencies may negatively affect brain function, while folic acid, vitamin $\mathrm{B}_{12}$ and iron deficiencies may affect the learning outcomes of children of all ages [1,33]. One of the consequences of insuficcient serum iron concentration is a reduced activity of brain enzymes, of which iron is one of the components [1]. Zinc deficiency may cause impairment of both cognitive and motor processes in children and increase the risk of hyperactivity or depression [1]. Vitamin D is associated with various neurobiological pathways and protects against neurodegeneration [33]. The active form of vitamin $\mathrm{D}$ is also responsible for proper bone mineralization, while calcium is the most important ingredient in the process of building bones and teeth. Magnesium has an effect on nerves and muscles functioning, and its deficiency leads to a decrease in bone mineral density [7].

The aim of the study was to determine the effect of selected dietary components, the nutritional status and sleep duration in children at pre-school ages (3-6-years old) on their emotional sphere, as well as the cognitive, physical and social development. The selection of dietary components for analysis was based on their role in development processes, according to scientific literature and the research conducted so far.

\section{MATERIAL AND METHODS}

The research was carried out in the Municipal Kindergarten in Ruciane-Nida during OctoberDecember 2018. Out of 140 children, 75 (34 girls and 41 boys), aged 3-6 years old, were randomly selected. The study group consitsed of 29 three year olds, 12 four year olds, 20 five year olds and 14 six year olds.

Parents of the subjects were informed about the purpose and methodology of the study and gave written consent to carry it out. The research consisted of a questionnaire, a 3-day food record, anthropometric measurements, and child development assessement tools. The research was approved by the Bioethics Committee of the Medical University of Bialystok, approval No. R-I-002/240/2018.

A quantitative diet evaluation was carried out using a 24-hour food recall, which was collected from the entire study group ( 75 children) from 3 days -2 week days and 1 weekend day. Parents recalled their children's meals eaten at home, which should typically constitute $25 \%$ of a child's total daily requirement, while the remaining $75 \%$ is covered by pre-school nutrition [6]. Information on this part of the food ration was obtained based on the menu implemented in the kindergarten, which was provided by the facility. The analysis of children's food ration was performed using the Diet 5.0 software, developed by the Food and Nutrition Institute in Warsaw. It takes into account losses of nutrients, vitamins and minerals arising from food processing and storage. The values of energy and selected dietary components were averaged and the level of norm implementation was assessed through comparison of nutrients supply with the values recommended in the "Nutrition standards for the Polish population" redacted by Jarosz [21]. Subjects were divided into two age groups (3-yearold children and 4-6-year-old children) according to the nutritional norms available. The group's energy requirement (EER) was established. It was assumed that protein should constitute $13 \%$ of total energy requirement fats - $35 \%$, and digestible carbohydrates - $52 \%$, and at the same time not less than $130 \mathrm{~g} /$ day. The desired ratio of animal to plant protein is about $2: 1$. The calculated values of vitamins and minerals were compared with the Recommended Dietary Allowance (RDA) for calcium, magnesium, iron, zinc, copper, B vitamins, vitamin C, eicosapentaenoic and docosahexaenoic acids, and Adequate Intake (AI) for dietary fiber, vitamin $\mathrm{E}$, vitamin $\mathrm{D}$ and iodine.

The proprietary questionnaire consisted ofquestions about vitamin and mineral supplementation among the subjects and their sleep duration.

Anthropometric measurements of subjects were taken, i.e. height and weight, using a scale with a stadiometer, and the Body Mass Index (BMI) was 
calculated. The values obtained were comparedwith the reference values using the growth charts for children aged 3-18 years old, created based on the data from the "Olaf and Ola" projects, which were coordinated by the Children's Memorial Health Institute [9, 23, 24, 31].

The following percentile ranges for height and weight were used:

- $<\mathrm{c} 3$ - well below norm - developmental disorders

- c3-c10 - below norm - control and observation required

- c25-c75 - narrow norm (correct development - the most optimal range)

- c10-c90 - broad norm (proper development)

- c90-97 - above norm - control and observation required

- >c97 - well above norm - developmental disorders

The nutritional status of children was assessed based on curves on growth charts, marked as underweight, overweight and obesity cut-offs. They meet the standards adopted for adults, i.e. $<18.5 \mathrm{~kg} / \mathrm{m}^{2}$ (underweight), $25.0-29.9 \mathrm{~kg} / \mathrm{m}^{2}$ (overweight), $>30 \mathrm{~kg} /$ $\mathrm{m}^{2}$ (obesity). The area between the underweight and overweight cut-offs indicated the correct body weight. No specific reference points proposed by the World Health Organization (WHO) were adopted because, according to the authors of the growth charts, they are inadequate for the population of Polish preschool children and lead to over diagnosis of obesity $[9,23$, 24, 31].

The development of the subjects was assessed using observation sheets for 3-, 4- and 5-year-olds and a of school readiness assessment for 6-year-olds. These assessment tools were developed by Biela and School and Pedagogical Publishers (WSiP), based on the core curriculum and further developed by kindergarten teachers $[2,3,4,5]$. They assessed the adequacy of the skills of observed children to their age during a twomonth observation (September and October). The assessment of physical development consisted of the analysis of skills in self-service activities, large and small motor skills. Child's emotional maturity was also checked by assessing their ability to experience and understand emotions, their independence and emotional resilience. Social development was verified based on the child's attitude towards peers and adults, as well as their compliance with the norms and principles in the kindergarten. Cognitive development level was assessed based on the skills and abilities in general knowledge, speech, memory, perceptiveness, visual-auditory coordination, readiness to speak a foreign language as well as mathematical skills and preparation for learning to read and write - depending on the child's age. The results were referred to the point scale prepared by the author of the sheets used, and converted into percentages.The level of child development (low, medium, high) was determined in the four studied areas $[2,3,4,5]$.

The results were statistically analyzed, using the Statistica 13 software, by StatSoft. The results are presented as means, standard deviations, minimum and maximum values and percentages. A Chi-square statistical test was used amongst nominal variables to check the relationship between the sleep duration, supplementation used and development level of children (low, medium, high). Spearman's rank correlation coefficient was also used to examine the correlation between the intake of selected dietary components (based on 24-hour fodd recall), nutritional status and the level of child development (presented as percentage). The results whose significance level was $p<0.05$ were considered statistically significant.

\section{RESULTS}

Table 1 presents the average age and basic anthropometric parameters of the study group by gender.

Height, weight and BMI values of all subjects ( $\mathrm{n}$ $=75$ ) were compared with reference values for boys and girls using growth charts. The height of $70.8 \%$ of the male subjects $(n=29)$ was normal in relation to age $-39 \%$ of them $(n=16)$ were within the narrow norm, and $31.8 \%(n=13)$ - within the broad norm. On the other hand, $29.2 \%$ of boys $(n=12)$ exceeded the upper or lower limit of the norm, and growth disorders were noticed in $14.6 \%$ of male children $(n=6)$. The height of $61.7 \%$ of female subjects $(n=21)$ was normal $-38.2 \%(n=13)$ in the narrow norm and $23.5 \%(n$

Table 1. Characteristics of the studied group of 3-6-year-old children

\begin{tabular}{|c|c|c|c|c|}
\hline & Gender & $\mathrm{n}=75$ & Mean \pm SD & Range (min-max) \\
\hline Age & \multirow{4}{*}{ Girls } & 34 & $4.3 \pm 1.2$ & $3-6$ \\
\hline Height $[\mathrm{cm}]$ & & & $106.2 \pm 10.2$ & $82-124$ \\
\hline Body weight $[\mathrm{kg}]$ & & & $17.9 \pm 3.7$ & $11-28$ \\
\hline BMI $\left[\mathrm{kg} / \mathrm{m}^{2}\right]$ & & & $15.80 \pm 1.76$ & $12.85-21.17$ \\
\hline Age & \multirow{4}{*}{ Boys } & 41 & $4.2 \pm 1.2$ & $3-6$ \\
\hline Height $[\mathrm{cm}]$ & & & $109.1 \pm 10.7$ & $93-131$ \\
\hline Body weight $[\mathrm{kg}]$ & & & $19.8 \pm 5.4$ & $11-36$ \\
\hline BMI $\left[\mathrm{kg} / \mathrm{m}^{2}\right]$ & & & $16.35 \pm 2.20$ & $11.45-24.59$ \\
\hline
\end{tabular}


$=8)$ - in the broad norm. The remaining percentage of the female subjects - $38.3 \%(\mathrm{n}=13)$ was outside the norm. In $14.8 \%$ of them $(n=5)$ the values of this anthropometric parameter exceeded the cut-offs, which meant that the deviations from the norm were so siginificantas to indicate the occurrence of growth disorders.

The weight of $73.2 \%$ of boys $(n=30)$ was ageadequate $-39 \%$ of boys $(n=16)$ were in the narrown norm range, and $34,2 \%(n=14)$ - in the broad norm. Deviations from the norms occurred in $26.8 \%$ of boys $(\mathrm{n}=11)$, and $12.2 \%$ of them $(\mathrm{n}=5)$ presented with abnormal body weight. The weight of $76.4 \%$ of girls (n $=26)$ was within the age-adequate norm $-52.9 \%(\mathrm{n}=$ $18)$ in the narrow norm and $23.5 \%(n=8)$ - in the broad norm. Body weight of $23.6 \%$ of female children $(n=8)$ exceeded the lower or upper limit of norm, with $11.8 \%$ of them $(n=4)$ presenting abnormal body weight. Figure 1 presents the weight-for-age and height-forage growth charts (percentile) for girls and boys aged
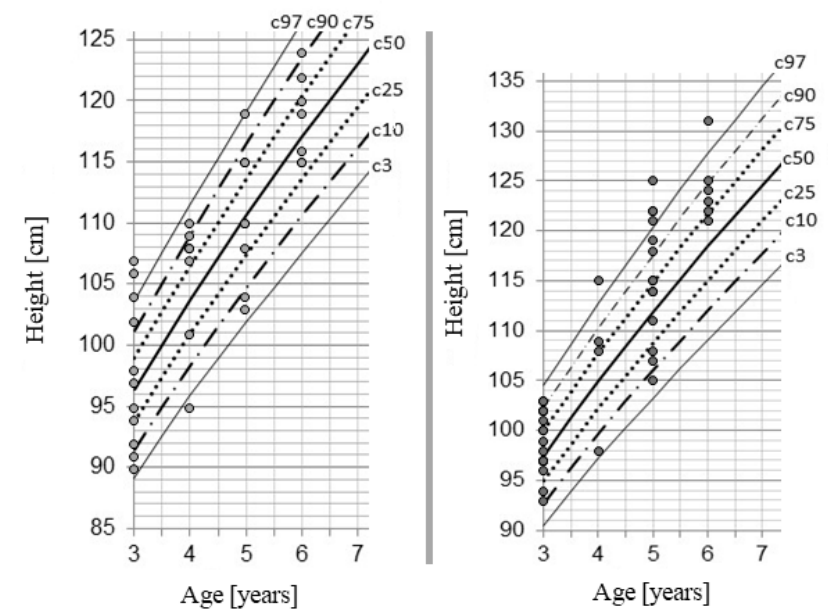

3-18 years (Olaf and Ola), which were marked with the subjects' values of these parameters.

Normal BMI was found in $68.3 \%$ of boys $(\mathrm{n}=28)$ and $73.5 \%$ of girls $(n=25)$. Overweight was found in $19.5 \%$ of boys $(n=8)$ and in $11.8 \%$ of girls $(n=4)$, obesity - in $7.3 \%$ of boys $(n=3)$ and $2.9 \%$ of girls $(n=$ 1 ), and underweight in $4.9 \%$ of boys $(n=2)$ and $11.8 \%$ of girls $(n=4)$. Figure 2 presents body mass index-forage growth charts (percentile) for girls and boys aged 3-18 years old (Olaf and Ola), which were marked with the subjects' BMI values.

The accurateness of the subjects'development ( $\mathrm{n}=$ 75) was also assessed based on the skills they should have possessat the age of 3, 4, 5 and 6 years old in terms of physical, emotional, social and cognitive development. Figure 3 shows the percentage of children from each age group with low, medium and high degree of development.

An assessment of the energy and nutritional value of the daily food ration was performed. Table
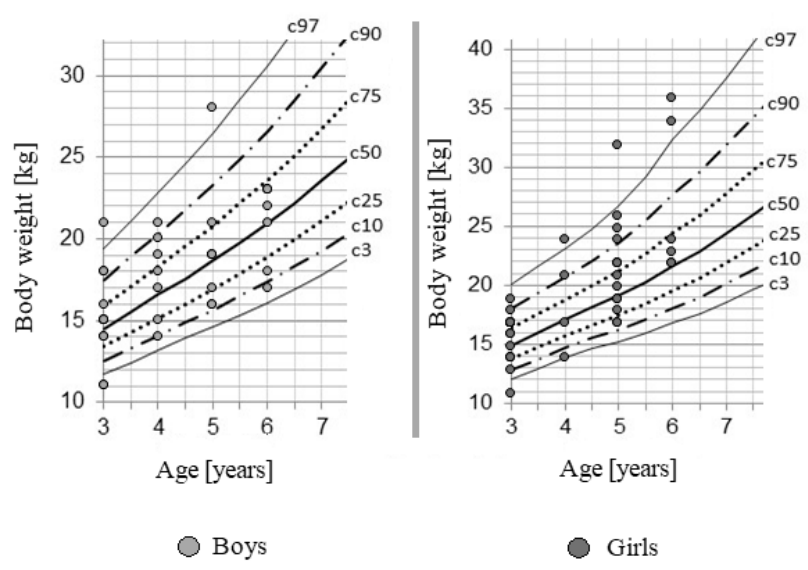

Figure 1. Percentiles of height and body weight of studied children
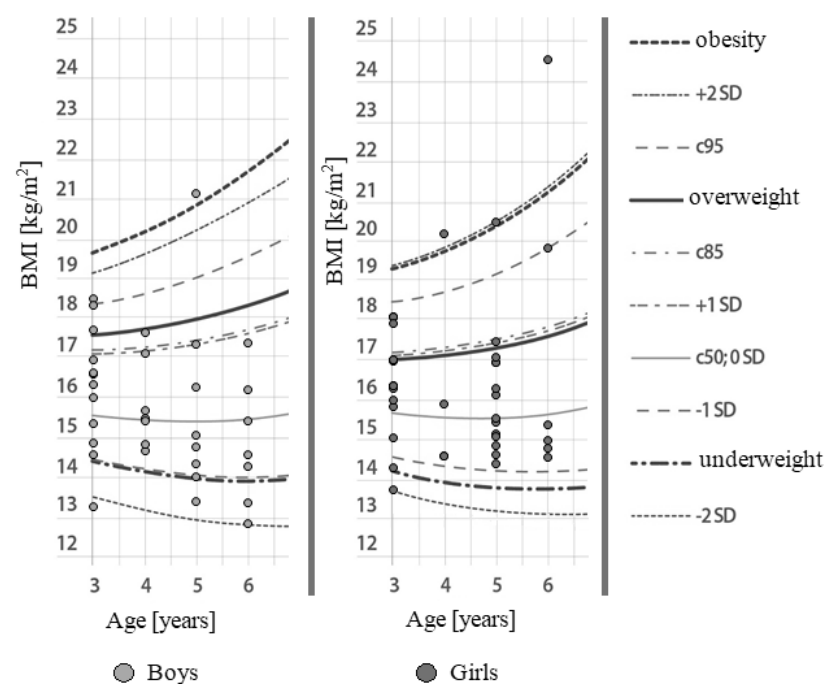

Figure 2. Nutritional status of studied children
2 presents the daily food ration of the subjects divided into two age groups- including both home and kindergarten nutrition. Energy requirement was met in accordance with the recommendations in both 3-year-old and 4-6-year-old children. The norm for protein was exceeded in all subjects, but more so in younger children. The animal to plant protein ratio was correct. The analysis shows that the study group had a dietary fat deficiency. The intake of available carbohydrates however, was appropriate. Dietary fiber intake in younger children was slightly above the norm, and in older children - it was adequate. Significant deficiencies of EPA and DHA as well as vitamin $\mathrm{D}$ were noticed in diets of all children.Vitamin E, calcium and iron deficienies also occurred in the whole study group. Iodine and folate intake were in line with requirements. In contrast, the remaining B 


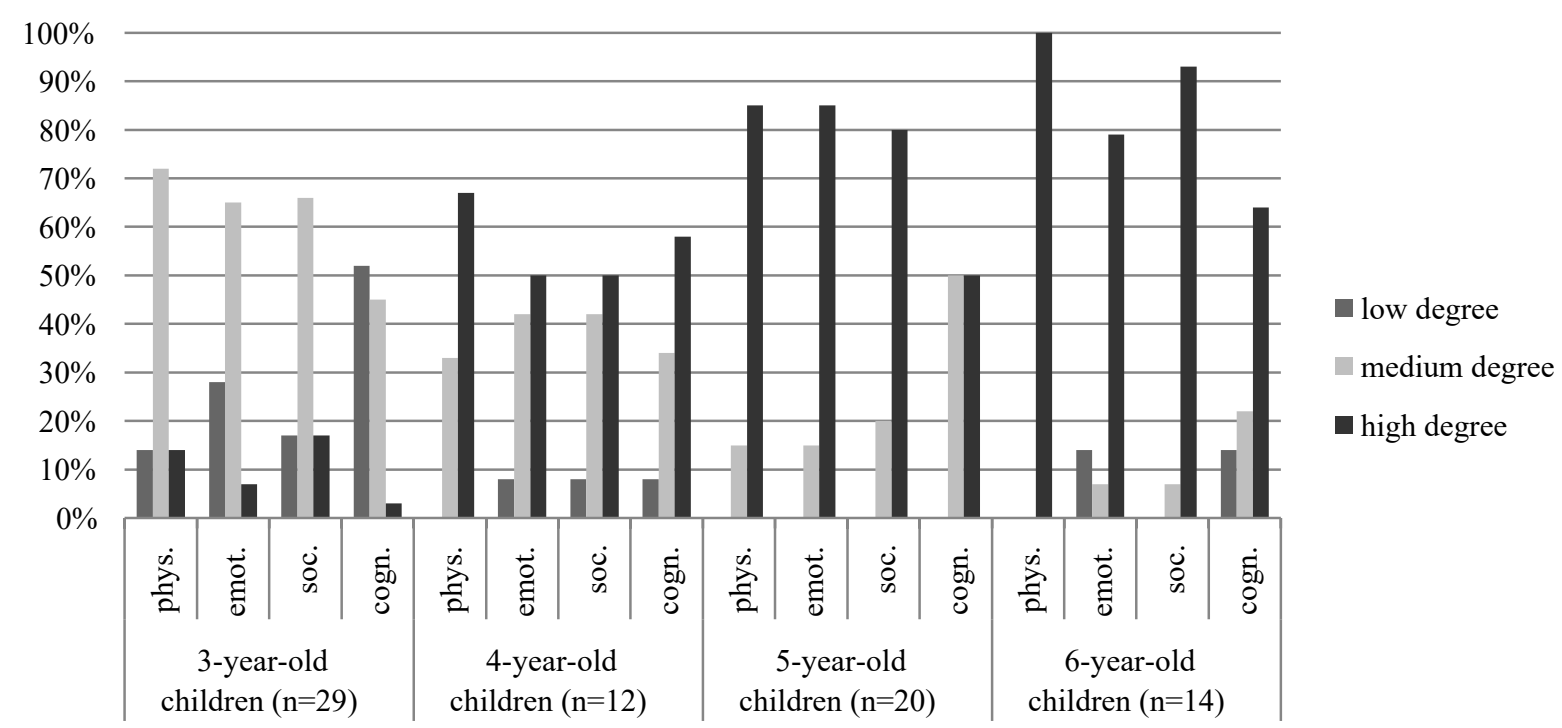

phys. - physical development;

soc. - social development; emot. - emotional development

cogn. - cognitive development

Figure 3. Degree of children development

Table 2. Daily food ration for 3-year-old and 4-6-year-old children

\begin{tabular}{|c|c|c|c|c|}
\hline & \multicolumn{2}{|c|}{3 -year-old children $(n=29)$} & \multicolumn{2}{|c|}{4 - 6 -year-old children $(n=46)$} \\
\hline & Mean \pm SD & $\%$ of standard* & Mean \pm SD & $\%$ of standard* \\
\hline Energy value of the diet [kcal] & $1170.33 \pm 183.99$ & 102 & $1239.70 \pm 227.84$ & 93 \\
\hline Protein $[\mathrm{g}]$ & $49.56 \pm 8.80$ & 132 & $52.67 \pm 10.82$ & 121 \\
\hline Animal protein $[\mathrm{g}]$ & $33.86 \pm 7.53$ & 156 & $34.92 \pm 8.78$ & 115 \\
\hline Plant protein $[\mathrm{g}]$ & $15.71 \pm 3.05$ & 158 & $17.75 \pm 4.47$ & 116 \\
\hline Fats $[\mathrm{g}]$ & $35.05 \pm 7.00$ & 80 & $37.70 \pm 9.83$ & 73 \\
\hline $\mathrm{EPA}+\mathrm{DHA}[\mathrm{mg}]$ & $112.24 \pm 180.49$ & 43 & $107.31 \pm 168.30$ & 41 \\
\hline Available carbohydrates $[\mathrm{g}]$ & $162.56 \pm 29.37$ & 108 & $171.01 \pm 34.48$ & 98 \\
\hline Dietary fiber $[\mathrm{g}]$ & $13.05 \pm 2.29$ & 112 & $13.55 \pm 2.91$ & 100 \\
\hline Vitamin E [mg] & $3.87 \pm 0.98$ & 76 & $4.79 \pm 2.60$ & 77 \\
\hline Thiamine [mg] & $0.69 \pm 0.16$ & 130 & $0.74 \pm 0.16$ & 126 \\
\hline Riboflavin [mg] & $1.39 \pm 0.25$ & 257 & $1.42 \pm 0.26$ & 242 \\
\hline Niacin [mg] & $8.87 \pm 2.26$ & 132 & $9.90 \pm 4.25$ & 126 \\
\hline Pyridoxine [mg] & $1.30 \pm 0.24$ & 238 & $1.34 \pm 0.33$ & 227 \\
\hline Cobalamin $[\mu \mathrm{g}]$ & $3.57 \pm 0.82$ & 346 & $3.66 \pm 0.98$ & 314 \\
\hline Vitamin C [mg] & $70.99 \pm 28.15$ & 158 & $71.98 \pm 40.19$ & 143 \\
\hline Folate $[\mu \mathrm{g}]$ & $170.74 \pm 34.27$ & 102 & $184.56 \pm 42.83$ & 94 \\
\hline Vitamin D $[\mu \mathrm{g}]$ & $1.58 \pm 1.34$ & 10,5 & $1.15 \pm 0.69$ & 8 \\
\hline Calcium [mg] & $675.42 \pm 145.96$ & 82 & $693.09 \pm 137.26$ & 72 \\
\hline Magnesium [mg] & $208.70 \pm 42.48$ & 213 & $224.43 \pm 46.69$ & 183 \\
\hline Iron [mg] & $6.94 \pm 1.31$ & 84 & $7.09 \pm 1.48$ & 74 \\
\hline Zinc [mg] & $6.14 \pm 1.19$ & 163 & $6.38 \pm 1.13$ & 138 \\
\hline Copper [mg] & $0.88 \pm 0.20$ & 260 & $0.92 \pm 0.21$ & 235 \\
\hline Iodine $[\mu \mathrm{g}]$ & $87.57 \pm 18.06$ & 98 & $93.09 \pm 25.83$ & 103 \\
\hline
\end{tabular}

SD - standard deviation EPA - eicosapentaenoic acid DHA - docosahexaenoic acid

*Nutrition standards for the Polish Population, amendment 2017. Food and Nutrition Institute., Warsaw, Poland 
vitamins, vitamin $\mathrm{C}$, magnesium, zinc and copper were supplied in excess compared to the norms.

The next stage of the study was to determine the effect of dietary components taken into account in the quantitative assessment of children's food ration (Table 2) on the level of their cognitive, emotional and physical development. Spearman's rank correlation coefficient has been applied. Statistically significant correlations $(p<0.05)$ were observed only in children in the older age group, namely in 4-6 year olds $(n=46)$ and only in the case of cognitive development.

A positive correlation $(\mathrm{r}=0.42, \mathrm{p}=0.004)$ was observed between the level of cognitive development and the vitamin $\mathrm{D}$ intake. A positive correlation $(r=0.34, p=0.020)$ was also found between the level of cognitive development and folate intake. In addition, a positive correlation $(\mathrm{r}=0.36, \mathrm{p}=0,014)$ was observed between the cognitive development level and vitamin E intake. A positive correlation $(\mathrm{r}=0.35, \mathrm{p}=0.017)$ was observed between the cognitive development level and magnesium intake. A positive correlation $(\mathrm{r}=0.40$, $\mathrm{p}=0.005$ ) was found between the cognitive development level and zinc intake. A positive correlation $(r=0.31$, $\mathrm{p}=0.034)$ was also observed between the cognitive development level and copper intake. An increased intake of the above-mentioned dietary components positively correlated with an increase in cognitive development in children aged 4-6. Correlations depict the intake of vitamins and mineral components in the diet, supplementation is not taken into account. Figure 4 presents scatter graphs of the above-mentioned correlations.

Theinfluence of the body massindex (the BMIvalues were allocated to their corresponding percentiles) on the social development of the subjected children has been assessed. Spearman's rank correlation coefficient has been applied. A statistically insignificant $(\mathrm{r}=-0.17$, $\mathrm{p}=0,148)$ negative correlation between the level of the social development $(\mathrm{n}=75)$ and the BMI was found. The increase of the BMI percentile was correlated to a lesser social development. Figure 5 presents the correlations graph.

Dietary supplements used by subjects were also assessed $(\mathrm{n}=75)$. Vitamin $\mathrm{D}$ supplements were used by $41.3 \%$ of respondents $(\mathrm{n}=31)$, omega -3 or fish oil - by $36 \%$ of respondents $(n=27)$, vitamin $C-$ by $34.7 \%$ of
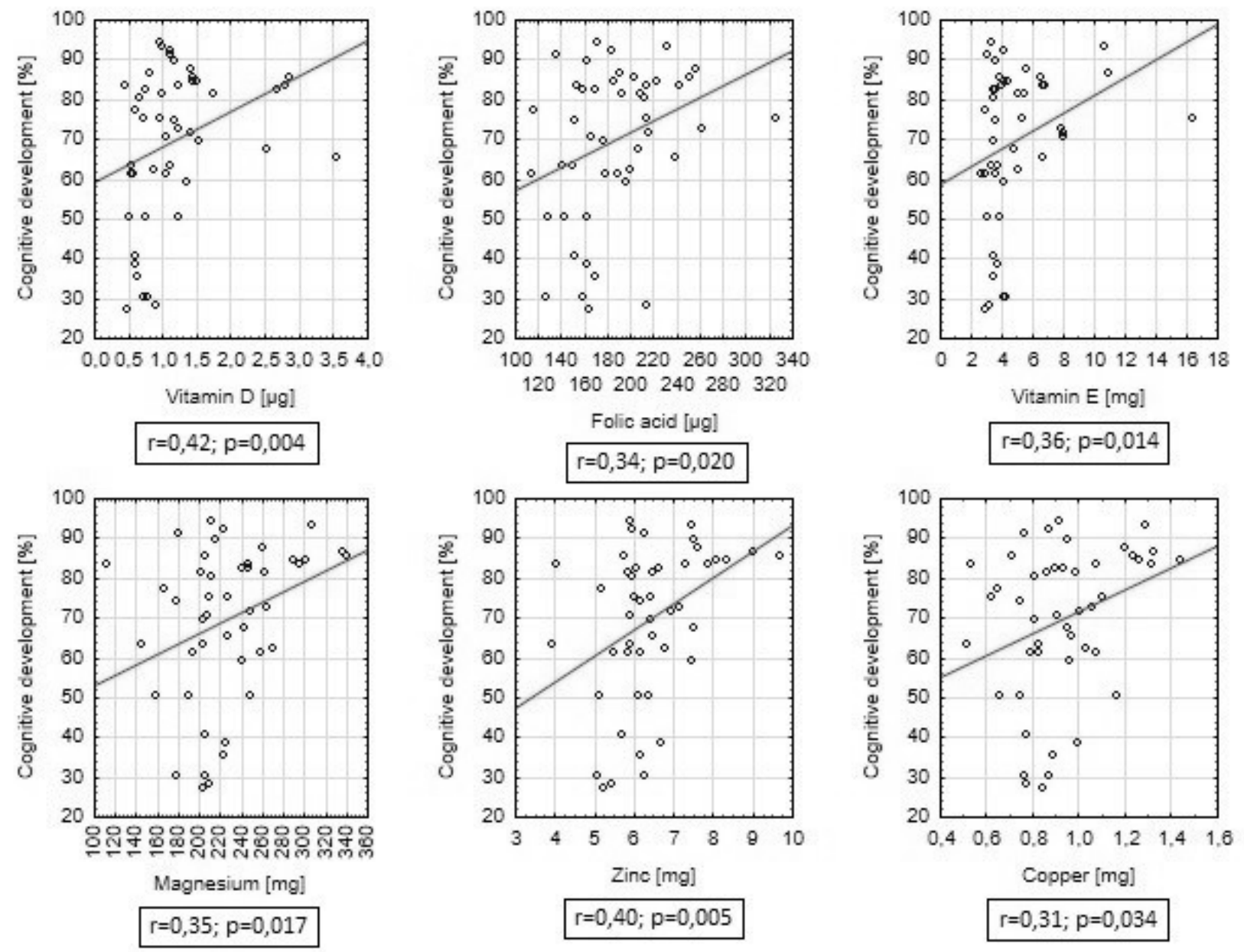

Figure 4. Correlations between the level of the cognitive development of children aged 4-6 and the intake of vitamins and minerals in the diet 


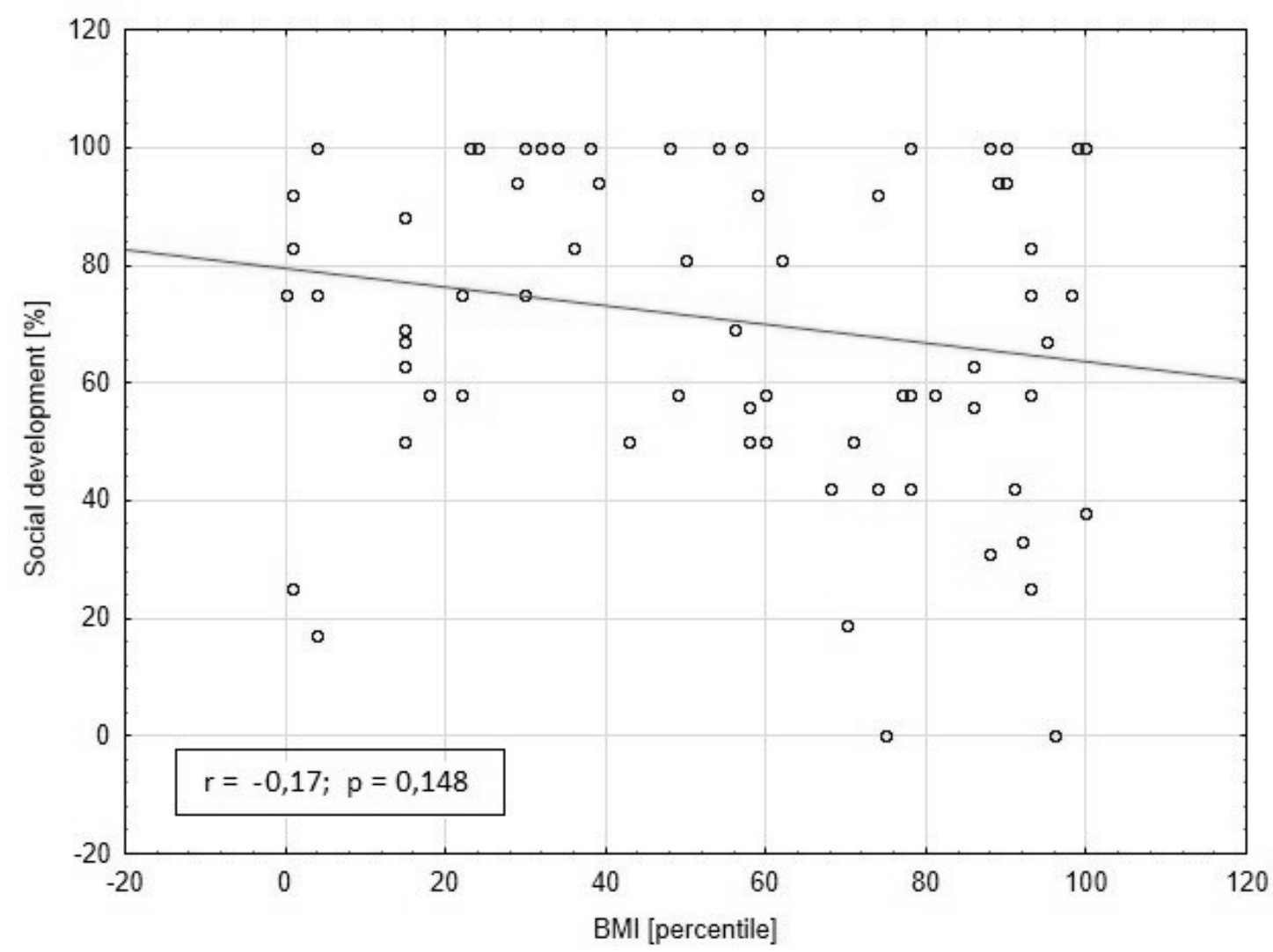

Figure 5. Correlation between children's social development and BMI percentile

respondents $(\mathrm{n}=26)$. Whereas $16 \%$ of children $(\mathrm{n}=12)$ received vitamin and mineral supplements. Calcium, magnesium and $\mathrm{B}$ vitamins were supplemented by $5.3 \%$ of children $(\mathrm{n}=4)$ and iron preparations - by $4 \%$ $(n=3)$ while $24 \%$ of respondents $(n=18)$ did not use any supplements at all.

Among children who did not supplement vitamin $\mathrm{D}(\mathrm{n}=44)$, the highest percentage was characterized by medium $(47.7 \%, \mathrm{n}=21)$ and low $(27.3 \%, \mathrm{n}=12)$ cognitive development levels. In contrast, among children supplementing vitamin $\mathrm{D}(\mathrm{n}=31)$, cognitive development level was high in $51.6 \%$ of them $(n=16)$. These differences were close to statistical significance $(\mathrm{p}=0.05)$.

Parents also provided information regarding the sleep duration of their children $(n=75)$. Sleep in $68 \%$ of them $(n=51)$ lasted 9-10 hours. In contrast, $22.6 \%$ of children $(n=17)$ slept $11-12$ hours. The daily sleep duration of $6.7 \%$ of respondents $(n=5)$ was 8 hours, and of $2.7 \%$ of children $(n=2)-6-7$ hours.

Among children who slept 9-10 hours a day $(\mathrm{n}=51)$, the majority had a high $(41.2 \%, \mathrm{n}=21)$ and medium $(45.1 \%, n=23)$ level of cognitive development. However, among children whose sleep duration was too short (6-8 hours) or too long (11-12 hours) (total $n=24)$, the $45.8 \%(n=11)$ had a low cognitive development level. These differences were statistical significance $(p<0.05)$.

\section{DISCUSSION}

During the first 4 years of life, a child's brain already reaches a mass only 200 grams smaller than that of the shaped adult brain. Because of this, during childhood special attention should be paid to intakes of all nutrients, minerals and vitamins essential for the proper structural and functional development of the brain [1].

The nutritional status of most of the subjects was normal. Underweight was observed in $5 \%$ of boys and $12 \%$ girls, overweight - in $20 \%$ of boys and $12 \%$ of girls, and obesity - in $7 \%$ and $3 \%$, respectively. Therefore, the abnormal nutritional status occurred in a much smaller percentage of children. However, given the fact that these data relate persons in a developmental period, which in turn affects all subsequent stages of life, these findings are disconcerting. A statistically significant negative correlation was found between the social development level and the body mass index, while increased body mass index correlated positively with the development of children. In their research, Pratt et al. explored the relationship between the quality of life of children and adolescents aged 8-18 years old and a normal BMI or excessive body weight. One of the components assessed with a questionnaire was social development, which was lower in those with abnormal body mass index [29]. 
The present study assessed the intake of dietary components that play a significant role in child development. Siginificant deficiencies of eicosapentaenoic acid (EPA) and docosahexaenoic acid (DHA) have been reported in children's diets. However, $36 \%$ of children surveyed supplemented omega-3 or fish oil. In our own research, no effects of EPA and DHA acid intake on cognitive development were found. The results of other authors' research are contradictory. Oyen et al. [28] observed a relationship between the consumption of oilyfish, which are a good source of omega-3, and the level of cognitive development of preschool children. However, Gispert et al. [16] did not find such relationship in school-age children, but noticed a positive effect of fish consumption on their emotional and social development.

The quantitative analysis of daily food rations of the subjects showed that their folate intake was sufficient. A statistically significant positive correlation was found between the level of cognitive development of 4-6-year-old children and the intake of dietary folate. No other authors' studies, in which the subjects were children, were found. Therefore, further research in this area is necessary.

In own research, a substantial deficiency of vitamin $\mathrm{D}$ in daily food rations of the subjected children was observed. However, some of their parents declared supplementation. The insufficient intake of the vitamin in children of a similar age group was also observed by Marcinek et al. [27]. According to the latest recommendations from 2018, a supplementation of 600-1000 IU of vitamin D is reccomended for preschool children from September to May. The precise dose of supplemenation depends on weight and dietary intake of vitamin D, In the months from May to September, with sufficient sunlight, supplementation in this age group is not necessary, but is recommended [32]. However, only $41 \%$ of the subjects supplemented vitamin D. Roszko-Kirpsza et al. [30] assessed vitamin D supplementation among 2-3-year-old children. Supplemenents were usedby less than $35 \%$. Our own research did not investigate the concentration of vitamin D metabolite in children's blood serum. However, taking into account the nutritional deficiencies in the study group and reduced skin synthesis during the time of research, i.e. in the autumn and winter, one can suppose that vitamin D levels would have been too low. In the research conducted by Eupińska et al., the level of dietary intake of this vitamin and the concentration of its metabolite in the blood serum of school-age children were analyzed. Subjects had both dietary and serum deficiencies. Only $8.5 \%$ of subjects had adequate vitamin D levels ( $\geq 30 \mathrm{ng} / \mathrm{ml})[26,32]$.

In this study, a statistically significant relationship was found between vitamin $\mathrm{D}$ supplementation in children and their cognitive development level. Among the subjects who did not supplement this vitamin, the highest percentages were characterized by medium and low levels of cognitive development, where as most children supplementing the vitamin had a high level of cognitive development. A statistically significant positive correlation was found between the level of cognitive development of 4-6-year-old children and dietary intake of vitamin D. Its increased intake positively correlated with an increase in cognitive development in children aged 4-6 years old. Zhu et al. observed the relationship between vitamin D concentration in umbilical cord blood of newborns and their subsequent neurocognitive development [39]. Other researchers have also noticed the relationship between vitamin $\mathrm{D}$ concentration in umbilical cord blood of newborns and speech development in early childhood [17].

Dietary intake of antioxidant vitamins was analyzed. No vitamin $\mathrm{C}$ deficiencies were observed. The recommended daily intake for this vitamin was exceeded in both younger and older children. However, the insufficient intake of the vitamin $\mathrm{C}$ in children of a similar age group was also observed by Marcinek et al. [27]. My own research has not confirmed an influence of the vitamin $\mathrm{C}$ intake on the cognitive development level. Liu et al. did not observe such a relationship either [25]. In own research, insufficient intake of vitamin $\mathrm{E}$ was noted. The requirement was met in $76-77 \%$. The results of Marcinek et al. research have also indicate the existence of diet insufficiencies vitamin E in children aged 1-4 [27]. In own research, a statistically significant correlation was observed between the vitamin $\mathrm{E}$ intake in the older group of children and their cognitive development level, which increased with increased intake of said vitamin. Liu et al. [25] observed the effect of prenatal vitamin E exposure on the intelligence quotient of pre-school children.

Magnesium intake in the subjects' food rations exceeded the recommended daily amounts. A statistically significant positive correlation was found between the cognitive development level of 4-6-year-old children and dietary magnesium intake. Increased intake of said mineral correlated with a higher level of cognitive development. Results of studies by other authors showed that children with attention deficit hyperactivity disorder (ADHD) had significantly lower serum magnesium levels compared to healthy children [10]. El Baza et al. [11] assessed the effect of magnesium supplementation in magnesiumdefficient children with ADHD. An improvement in cognitive function was observed in the group of children who used supplementation. In contrast, no such improvement was observed in the control group. However, the size of the study group was small. 
Randomized, blinded studies have not demonstrated the effectiveness of supplementation in treating such disorders in children with ADHD [14].

In own research, iron deficiencies were noted in both younger and older children. No relationship was found between dietary iron intake of children and their cognitive processes. Fuglestad et al. observed though, that iron deficiency in adopted children correlated with their worse cognitive development [13].

Dietary zinc intake in the studied group exceeded the recommended values. It has been observed that its increase positively correlates with the level of cognitive development of 4-6-year-old children. Fuglestad et al. [13] found that zinc deficiency affected the neurodevelopmental functions of adopted children. It was correlated with impairment of their memory. De Moura et al. [8] conducted a research on zinc supplementation among preschool and early school-age children without identified deficiencies. Their results showed the impact of supplementation on improvement of long-term memory and logical thinking.

In own research, copper requirement was exceeded more than two-fold, in both 3-year-olds and 4-6-yearolds. A statistically significant positive correlation was found between the level of cognitive development of 4-6-year-old children and dietary copper intake. An increased intake of said mineral positively correlated with an increase in cognitive development. Adequate copper intake has a positive effect on cognitive functions, as copper is essential for normal brain function [1]. However, an excessive intake of this micronutrient can negatively affect cognitive processes and cause cognitive disorders. Zhou et al. [38] observed that excessive levels of copper in the blood serum have a negative effect on memory in school-age children.

The systematic review of research of Guzek et al. has indicated a correlation between a proper intake of fruit and vegatables by children at a pre-school and school age and a lower risk of behavioural and emotional problems or depression. Fruit and vegatables are a source of numerous vitamins and minerals, including those previously analysed in own research (folic acid, vitamin E, calcium, magnesium or copper) [20].

In the present study, the average sleep duration of the subjects was assessed. Sleep in $68 \%$ of them lasted 9-10 hours. In contrast, $22.6 \%$ of children slept for 11-12 hours. The daily sleep duration of $9.4 \%$ of respondents was 6-8 hours. A statistically significant correlation was shown between children's sleep duration and their cognitive development. Among children who slept 9-10 hours a day, most were characterized by a high and medium degree of cognitive development. However, majority of children whose sleep was shorter (6-8 hours) or longer (11-
12 hours) had a low level of cognitive development. Based on the conducted research, Kocevska et al. found that not only insufficient, but also excessive sleep duration adversely affects children's cognitive functions. The effect of sleep duration of 2-year-old children on their cognitive development at the age of 6 was studied [22]. According to the results of other authors' studies conducted among children up to the age of two, short sleep duration correlated with worse cognitive development. In addition, they observed that night sleep had a greater impact on child development than day time sleep [35]. Velten-Schurian et al. [36] also noted the effect of sleep duration on the cognitive processes in children. Insufficient sleep was associated with inappropriate behavior and problems with concentration. Gruber et al. [19] confirmed the occurrence of more frequent concentration disorders among children with insufficient sleep duration. The results of other studies by this author also indicate a relationship between sleep duration and emotional stability [18]. Giganti et al. observed the positive effect of naps on conscious memory functions in pre-school children [15].

To date, little research has been done on effects of dietary components, supplementation and various lifestyle components on child development. Own research, and research conducted by other authors so far, indicate the existence of such relationship. Therefore, further research in this topic is necessary.

\section{CONCLUSIONS}

1. The diet of the subjected children was not properly balanced. There was an insufficient intake of fats, EPA and DHA acids, vitamin D, vitamin E, calcium and iron. To meet the demand, the supply of the given ingredients should be higher.

2. It was found that an adequate intake of folates, vitamin $\mathrm{D}$, vitamin $\mathrm{E}$, magnesium, zinc and copper in the diet correlated with a higher level of cognitive development of 4-6-year-old children. The research emphasize how important it is to control the intake of the vitamins and minerals by children to ensure their proper development.

3. A positive influence of vitamin D supplementation on the cognitive development of the subject group was observed. Children who received supplements of the vitamin displayed a higher level of the cognitive development in comparison to those who did not. It is essential to promote the realization of the current recommendations for the supplementation of the vitamin D.

4. Excessive body weight correlated with a lower level of social development in pre-school children.

5. The influence of the daily sleep length on the cognitive development of the children subjected 
to the study was observed. Both too short and too long sleep lengths were connected with a lower level of development.

6. Application of the proper nutrition and healthy lifestyle principles supports a proper child development. All dietary components should be balanced, however some nutrients are of especial significance during the childhood development and therefore their optimal intake is essential for this developmental period.

\section{Conflict of interests}

The authors declare no conflict of interest.

\section{REFERENCES}

1. Anjos T., Altmäe S., Emmett P., Tiemeier H., ClosaMonasterolo R., Luque V., Wiseman S., Pérez-García M., Lattka E., Demmelmair H., Egan B., Straub N., Szajewska H., Evans J., Horton C., Paus T., Isaacs E., van Klinken JW., Koletzko B., Campoy C.; NUTRIMENTHE Research Group: Nutrition and neurodevelopment in children: focus on NUTRIMENTHE project. Eur J Nutr 2013; 52:1825-1842 doi 10.1007/s00394-013-0560-4.

2. Biela A.: Observation sheets for 3-year-old children. In: Karamuz K., Jaszczuk M., Kaszkowiak M. Methodological Guide. Warsaw, WSiP, 2018 (in Polish).

3. Biela A.: Observation sheets for 4-year-old children. In: Karamuz K., Jaszczuk M., Kaszkowiak M.: Methodological Guide. Warsaw, WSiP, 2018 (in Polish).

4. Biela A.: Observation sheets for 5-year-old children. In: Karamuz K., Jaszczuk M., Kaszkowiak M. Methodological Guide. Warsaw, WSiP, 2018 (in Polish)

5. Biela A.: Observation sheets for 6-year-old children. In: Karamuz K., Jaszczuk M., Kaszkowiak M. Methodological Guide. Warsaw, WSiP, 2018 (in Polish).

6. Charzewska J.: Nutrition recommendations for implementers of basic nutritional requirements of children in kindergartens. Warsaw, IŻŻ, 2011 (in Polish).

7. Dardzińska J., Chabaj-Kędroń H., Matgorzewicz $S$.: Osteoporosis as a social and civilization disease prevention methods. Hyg Pub Health 2016; 51: 2330 (in Polish).

8. de Moura J., de Moura E., Alves C., de Lima Vale S., Dantas M., de Araújo Silva A., das Graças Almeida M., Leite L., Brandão-Neto J.: Oral Zinc Supplementation May Improve Cognitive Function in Schoolchildren. Biol Trace Elem Res 2013;155:23-28, doi 10.1007/ s12011-013-9766-9.

9. de Onis M., Onyango A., Borghi E., Siyam A., Nishidaa C., Siekmanna J.: Development of a WHO growth reference for school-aged children and adolescents. Bulletin of the World Health Organization 2007; 85: 9 doi: 10.2471/blt.07.043497.

10.Effatpanah M., Rezaei M., Effatpanah H., Effatpanah Z. , Varkaneh H., Mousavi S., Fatahi S., Rinaldi G., Hashemi R.: Magnesium Status and Attention Deficit Hyperactivity Disorder (ADHD): A Meta-
Analysis. Psychiatry Res 2019;274:228-234 doi: 10.1016/j.psychres.2019.02.043.

11. El Baza F., AlShahawi H., Zahra S., AbdelHakim R.: Magnesium supplementation in children with attention deficit hyperactivity disorder. Egypt J Med Hum Genet 2016;17, 63-70, doi: 10.1016/j.ejmhg.2015.05.008.

12. Food and Nutrition Institute. The principles of proper nutrition 2016. Available: http://www.izz.waw.pl/ zasady-prawidlowego-zywienia. Accessed: 21.02.2020 (in Polish).

13. Fuglestad A., Kroupina M., Johnson D., Georgieff $M$ : $\quad$ Micronutrient status and neurodevelopment in internationally adopted children. Acta Pædiatr 2016;105:67-76 doi:10.1111/apa.13234.

14. Ghanizadeh A.: A systematic review of magnesium therapy for treating attention deficyt hyperactivity dis order. Arch Iran Med 2013;16:412-7.

15. Giganti F., Arzilli C., Conte F., Toselli M., Viggiano $M P$., Ficca $G$.: The effect of a daytime nap on priming and recognition tasks in preschool children. Sleep 2014;37: 1087-1093 doi: 10.5665/sleep.3766.

16. Gispert-Llaurado M., Perez-Garcia M., Escribano J., Closa-Monasterolo R., Luque V., Grote V., Weber M., Torres-Espinola F.J., Czech-Kowalska J., Verduci E., Martin F., Piqueras M.J., Koletzko B., Decsi T., Campoy C., Emmett P.M.: Fish consumption in midchildhood and its relationship to neuropsychological outcomes measured in 7-9 year old children using a NUTRIMENTHE Neuropsychological battery. Clin Nutr 2016;35(6):1-7, doi: 10.1016/j.clnu.2016.02.008.

17. Gould J., Anderson A., Yelland L., Smithers L., Skeaff M., Zhou S., Gibson R., Makrides M.: Association of cord blood vitamin D with early childhood growth and neurodevelopment. J Paediatr Child Health 2017; 53 (1) : 75-83 doi:10.1111/jpc.13308.

18. Gruber R., Cassoff J., Frenette S., Wiebe S., Carrier $J .:$ Impact of sleep extension and restriction on children's emotional lability and impulsivity. Pediatr 2012;130(5):1155-1161, doi: 10.1542/peds.2012-0564.

19. Gruber R., Michaelsen S., Bergmame L., Frenette S., Bruni O., Fontil L. Carrier J.: Short sleep duration is associated with teacher-reported inattention and cognitive problems in healthy school-aged children. Nat Sci Sleep 2012;4:33-40 https://doi.org/10.2147/NSS. S24607.

20.Guzek D., Głąska D., Groele B., Gutkowska K.: Role of fruit and vegetables for the mental health of children: a systematic review. Rocz Panstw Zakl Hig 2020;71(1);513 doi: 10.32394/rpzh.2019.0096.

21. Jarosz M.: Food and Nutrition Institute: Nutrition standards for the Polish Population, amendment 2017. Available: $\quad$ https://ncez.pl/upload/normy-net-1.pdf. Accessed: 21.02.2020 (in Polish).

22.Kocevska D., Rijlaarsdam J., Ghassabian A., Jaddoe V., Franco O., Verhulst F., Tiemeier H.: Early Childhood Sleep Patterns and Cognitive Development at Age 6 Years: The Generation R Study. J Pediatr Psychol 2017;42(3):260-268 doi: 10.1093/jpepsy/jsv168.

23. Kułaga Z., Grajda A., Gurzkowska B., Góźdź M., Wojtyło M., Świąder A., Różdżýska-Światkowska A., 
Litwin M.: Polish 2012 growth references for preschool children. Eur J Pediatr 2013;172:753-761.

24.Kułaga Z., Różdżyńska-Świątkowska A., Grajda A., Gurzkowska B., Wojtyto M., Góźdź M., ŚwiąderLeśniak A., Litwin M.: Growth charts for the assessment of growth and nutritional status of Polish children and youth from birth to 18 years of age. Stand Med Pediatr 2015, 12: 119-135 (in Polish).

25.Liu Y., Chen Q., Wei X., Chen L., Zhang X, Chen K., Chen $J$., $L i$ T.: Relationship between perinatal antioxidant vitamin and heavy metal levels and the growth and cognitive development of children at 5 years of age. Asia Pac J Clin Nutr 2015; 24(4): 650-658 doi: 10.6133/ apjen.2015.24.4.25.

26. Łupińska A., Chlebna-Sokót D.: Factors affecting on the vitamin D concentration in blood serum of early schoolage children with excess body weight. Post N Med 2016; 29 (10): 709-715 doi: 10.5604/08606196.1222456 (in Polish).

27. Marcinek K., Wójciak R., Krejpcio Z.: Assessment of the nutritional value of daily food rations of children aged 1-4 years. Rocz Panstw Zakl Hig 2016;67(2):169-177.

28.Oyen J. , Kvestad I., Midtbø L., Graff I., Hysing M., Stormark K., Markhus M., Frøyland V., Koletzko B., Demmelmair H., Dahl L., Lie Ø., Kjellevold M.: Fatty Fish intake and cognitive function: FINS-KIDS, a randomized controlled trial in preschool children. BMC Med. 2018; 16(1): 41 doi: 10.1186/s12916-0181020-z.

29. Pratt K., Lamson A., Swanson M., Lazorick S., Collier $D$.: The importance of assessing for depression with HRQOL in treatment seeking obese youth and their caregivers. Qual Life Res 2012; 21:1367-1377, doi 10.1007/s11136-011-0042-1.

30.Roszko-Kirpsza I., Olejnik B., Kulesza M., Jabłoński R., Czerech E., Maciorkowska E.: Nutrition for rural children in aged 2-3-year-old. Probl Hig Epidemiol 2012;93(3):605-612 (in Polish).

31. Różdżyńska-Świątkowska A. , Kułaga Z. , Grajda A. , Gurzkowska B. , Góźdź M. , Wojtyło M., Świąder A. , Litwin M.: Reference values for height, weight and body mass index for assessing the growth and nutritional status of children and adolescents aged 3-18 years old. Stand Med /Pediatr 2013;11-21 (in Polish).

32.Rusińska A., Ptudowski P., Walczak M., BorszewskaKornacka M., Bossowski A., Chlebna-Sokół D., Czech-
Kowalska J., Dobrzańska A., Franek E., Helwich E., Jackowska T., Kalina M., Konstantynowicz J., Książyk J., Lewiński A., Lukaszewicz J., MarcinowskaSuchowierska E., Mazur A., Michatus I., PeregudPogorzelski J., Romanowska H., Ruchała M., Socha P., Szalecki M., Wielgoś M., Zwolińska D., Zygmunt $A$.: Rules for supplementation and treatment vitamin D - Amendment 2018. Post Neonatol 2018;24:1-24 doi: 10.31350/postepyneonatologii/2018/1/ PN2018001 (in Polish).

33. Scarmeas N, Anastasiou CA, Yannakoulia M: Nutrition and prevention of cognitive impairment. The Lancet Neurology 2018;17:1006-1015, doi: https://doi. org/10.1016/S1474-4422(18)30338-7.

34.Scharf R., Scharf G., Stroustrup A.: Developmental Milestones. Pediatr Rev 2016;37(1): 25-38, doi: https:// doi.org/10.1542/pir.2014-0103.

35. Smithson L. Baird T., Tamana S., Lau A., Mariasine J., Chikuma J., Lefebvre D., Subbarao P., Becker A., Turvey S., Sears M., Beal D., Pei J., Mandhane P.: Shorter sleep duration is associated with reduced cognitive development at two years of age. Sleep Med 2018; 48:131e139 https://doi.org/10.1016/j.sleep.2018.04.005.

36. Velten-Schurian K., Hautzinger M., Poets CF., Schlarb $A A$..: Association between sleep patterns and daytime functioning in children with insomnia: The contribution of parent-reported frequency of night waking and wake time after sleep onset. Sleep Med 2010;11(3):281-288 doi: 10.1016/j.sleep.2009.03.012.

37. Williams A., Suchdev P.: Assessing and Improving Childhood Nutrition and Growth Globally. Pediatr Clin N Am 2017;64:755-768 http://dx.doi.org/10.1016/j. pcl.2017.03.001.

38.Zhou G., Ji X., Cui N., Cao S., Liu C., Liu J.: Association between Serum Copper Status and Working Memory in Schoolchildren. Nutr 2015;7:7185-7196; doi:10.3390/ nu7095331.

39. Zhu P., Tong S., Hao J., Tao R., Huang K., Hu W., Zhou Q., Jiang X., Tao F.: Cord Blood Vitamin D and Neurocognitive Development are Nonlinearly Related in Toddlers. J Nutr 2015;145:1232-8. doi:10.3945/ jn.114.208801.

Received: 29.06.2020

Accepted: 02.09.2020 